\title{
Nye diagnosekriterier for Alzheimers sykdom
}

\author{
Nylig ble nye diagnosekriterier for Alzheimers sykdom publisert. Den viktigste forandringen er at diagnosen \\ nå kan stilles tidligere, før demens er utviklet. En annen viktig endring er at biomarkører fra spinalvæske \\ samt MR- og PET-undersøkelse nå kan bidra til diagnostiseringen.
}

Antallet personer med demens forventes å øke kraftig de neste 30 årene på grunn av økende antall eldre (ramme 1) $(1,2)$. Dette medfører store samfunnsøkonomiske utfordringer (3), i tillegg til redusert funksjon og livskvalitet hos dem som rammes og deres pårørende. Alzheimers sykdom er den hyppigste årsaken til demens og kjennetegnes patologisk av amyloide plakk i hjernebarken, intranevronale taufibriller («floker») og nevrontap, særlig i entorhinal hjernebark og hippocampus i mediale temporallapp $(4,5)$.

\section{Ny forskning}

De nåværende diagnostiske kriteriene for Alzheimers sykdom ble publisert i 1984 (6). Dette innledet en periode med store fremskritt når det gjelder kunnskap om sykdommens patofysiologiske prosesser. Vi vet nå at den starter ti år eller mer før de første symptomer opptrer, og at endret amyloidmetabolisme ofte opptrer tidlig (7). De tidligste kliniske stadier av Alzheimers sykdom, «mild kognitiv svikt» (ramme 2), er blitt kartlagt $(8,9)$. Forskning har vist at andre viktige demenssykdommer, som vaskulær demens, demens med lewylegemer og frontotemporal demens, klinisk og patofysiologisk overlapper Alzheimers sykdom. Ny forskning har bidratt til utvikling av bedre

\section{Ramme 1}

Kliniske kriterier for demens (2)

Demens er et kognitivt og atferdsmessig syndrom som:

- Påvirker yrkesmessig eller daglig funksjonsevne

- Representerer en forverrelse i forhold til tidligere funksjonsevne

- Ikke kan forklares på grunn av depresjon eller delirium

- Er påvist ved

- sykehistorie fra pasient og informant

- objektiv kognitiv testing

- Involverer minst to av følgende:

- Svekket innlæring av nytt materiale

- Nedsatt abstraksjonsevne og resonnering

- Nedsatt visuospatiell funksjon

- Svekket språkevne

- Personlighetsendring biomarkører. Disse er av en adhocekspertgruppe blitt anbefalt inkludert i nye forskningskriterier for Alzheimers sykdom (10).

\section{Nye kriterier}

I 2009 tok det amerikanske National Institute of Aging, sammen med Alzheimer's Association, initiativ til en serie med rundebordsmøter med formålet å revidere de diagnostiske kriterier for Alzheimers sykdom. Tre ulike grupper med representanter fra akademia og industri ble nedsatt for å utarbeide forslag til nye kriterier for de ulike stadiene. Forslagene til kriterier ble publisert på Internett i 2010 og ble deretter gjenstand for offentlig diskusjon. På bakgrunn av disse drøftingene ble de endelige versjonene publisert våren $2011(2,9,11)$. Kriteriene er blitt mye diskutert (12-14).

De nye kriteriene inneholder to viktige, nye elementer. For det første vektlegges sykdommens ulike stadier. Dette muliggjør at diagnosen kan stilles tidligere, før demens er inntrådt klinisk. For det annet foreslås ulike biomarkører som kan bidra til diagnostikk av Alzheimers sykdom - dette i motsetning til de tidligere kriteriene, som var basert utelukkende på kliniske symptomer og funn. De nye kriteriene er imidlertid ennå ikke validert i prospektive studier.

\section{Biomarkører}

De mest aktuelle biomarkørene til bruk i diagnostikk av Alzheimers sykdom er strukturell MR for å påvise atrofi av spesifikke hjerneområder, særlig mediale temporallapp, samt konsentrasjonene i cerebrospinalvæske (CSV) av betaamyloid, tau og fosforylert tau (2). I tillegg er det utviklet molekylære bildedannende teknikker som visualiserer patologiske plakk ved hjelp av PET-teknikk med ligander som binder seg til amyloidfibriller i hjernen og som også visualiserer redusert glukosemetabolisme i temporal- og parietalbarken. Alle disse teknikkene er basert på sentrale patofysiologiske prosesser ved sykdommen, og det foreligger en rekke undersøkelser som viser at de har god sensitivitet og spesifisitet til å skille tidlig Alzheimers sykdom fra tilstander hos friske eldre. (9).

Ifølge de nye kriteriene kan «demens ved Alzheimers sykdom» diagnostiseres ut fra klinisk undersøkelse alene, men biomarkørene kan si noe om sannsynligheten for at de kliniske symptomene og funnene skyldes Alzheimers sykdom. Mer kunnskap behøves før biomarkørene kan anbefales brukt rutinemessig, og kriteriene for «preklinisk Alzheimers sykdom», som er basert på biomarkører alene, er ment utelukkende til bruk i forskning (11).

\section{Uavklarte forhold}

Det gjenstår mye arbeid, blant annet med å standardisere måling av biomarkører i cerebrospinalvæske mellom ulike laboratorier (15). Det må også oppnås konsensus for tolking av verdier som ligger i grenseområdet mellom normale og patologiske tilstander og for diskrepans mellom ulike biomarkører. Biomarkørene er heller ikke spesifikke nok til å skille mellom Alzheimers sykdom og andre demenssykdommer, som vaskulær demens og demens med lewylegemer (16). Det er ikke avklart i hvilken grad biomarkørene er nyttige i de aller eldste aldersgrupper. Enkelte undersøkelser, blant annet utført av norske forskere (17), tyder på at større presisjon kan oppnås ved å kombinere MR-undersøkelse og undersøkelse av ulike biomarkører i cerebrospinalvæske, men dette må verifiseres i større studier.

Så lenge det ikke finnes forebyggende eller sykdomsmodifiserende behandling er det også viktige etiske problemstillinger knyttet til tidlig diagnostikk av en slik alvorlig, progredierende hjernelidelse som Alzheimers sykdom, og til de samfunnsøkonomiske implikasjoner ved en forventet betydelig økning av diagnostikk av predemens eller preklinisk sykdom. Det er foreløpig heller ikke vist at pasienter med mild kognitiv svikt responderer på antidemensmidler (18). Forhåpentligvis kan de nye kriteriene også bidra til at en mer homogen og relevant populasjon kan inngå i slike studier og dermed bedre muligheten for å avklare hvorvidt det finnes en effekt eller ikke.

\section{Ramme 2}

Kliniske kriterier for mild kognitiv svikt $^{1}$ (9)
- Subjektivt svekket kognisjon
- Redusert kognitiv funksjon ved testing, særlig av hukommelse
- Bevart evne til selvstendig fungering
- De kliniske kriterier for demens ikke oppyylt

1Alle kriteriene må være oppfylt 


\section{Konklusjon}

Presis og tidlig diagnostikk av Alzheimers sykdom er viktig for å kunne gi korrekt prognostisk informasjon til pasient og pårørende. De nye diagnostiske kriteriene må imidlertid valideres i prospektive studier og vil måtte bli revidert når ny forskning gjør det naturlig. Vi mener likevel at de nye kriteriene utgjør et viktig fremskritt, både i klinisk praksis og for utviklingen av nye sykdomsmodifiserende behandlinger.

\section{Dag Aarsland}

Regionalt kompetansesenter for eldremedisin og samhandling

Stavanger universitetssjukehus

og

Karolinska Institutets Alzheimercentrum

och Geriatriska kliniken

Karolinska Universitetssjukhuset

og

Fakultetsdivisjonen Akershus universitetssykehus Universitetet i Oslo

\section{Arvid Rongve}

Seksjon for alderspsykiatri

Klinikk for psykisk helsevern

Haugesund sykehus

og

Seksjon for forskning, Helse-Fonna

\section{Tormod Fladby}

Nevrologisk avdeling

Akershus universitetssykehus

og

Fakultetsdivisjonen Akershus universitetssykehus

Universitetet i Oslo

\section{Ingelin Testad}

Regionalt kompetansesenter for eldremedisin og samhandling

Stavanger universitetssjukehus

\section{Miia Kivipelto}

\section{Bengt Winblad}

Karolinska Institutets Alzheimercentrum och

Geriatriska kliniken

Karolinska Universitetssjukhuset

Dag Aarsland (f. 1959) er dr.med. og spesialist i psykiatri. Han er forskningsleder og seksjonsoverlege ved Regionalt kompetansesenter for eldremedisin og samhandling (SESAM), Stavanger universitetssjukehus, og professor i demensforsknings ved Centrum för Alzheimerforskning, Karolinska Institutet. I tillegg er han tilknyttet Universitetet i Oslo og Akershus universitetssykehus.

Ingen oppgitte interessekonflikter.
Arvid Rongve (f. 1969) er seksjonsoverlege og forsker ved Seksjon for alderspsykiatri og forskningsseksjonen ved Haugesund sykehus, Helse-Fonna. Forskningsinteresse er demens, spesielt demens med lewylegemer.

Ingen oppgitte interessekonflikter.

Tormod Fladby (f. 1959) er professor i nevrologi og avdelingssjef ved nevroklinikken ved Akershus universitetssykehus, som bl.a. innbefatter en hukommelsesklinikk. Han leder en forskningsgruppe som fokuserer på etiologi, tidligdiagnostikk og utprøvende behandling for kognitiv svikt og demens.

Ingen oppgitte interessekonflikter.

Ingelin Testad (f. 1963) er postdoktor og senterleder for Regionalt kompetansenseter for eldremedisin og samhandling (SESAM), Helse Vest.

Ingen oppgitte interessekonflikter.

Miia Kivipelto er professor i klinisk geriatrisk epidemiologi ved Karolinska Institutets Alzheimercentrum og nestleder ved Karolinska Institutets Forskningscenter for aldring. Hun er forskningsdirektør for avdeling for nevroepidemiologi ved universitetet i Øst-Finland. Hun er også overlege i geriatri ved hukommelsesklinikken, Karolinska Universitetssjukhuset. Ingen oppgitte interessekonflikter.

Bengt Winblad (f. 1943) er dr.med., professor ved Karolinska Institutet og overlege ved Geriatriska kliniken i Huddinge. Han er direktør for Karolinska Institutets Alzheimercentrum. Ingen oppgitte interessekonflikter.

\section{Litteratur}

1. Wimo A, Jonsson L, Winblad B. An estimate of the worldwide prevalence and direct costs of dementia in 2003. Dement Geriatr Cogn Disord 2006; 21: 175-81.

2. McKhann GM, Knopman DS, Chertkow $\mathrm{H}$ et al. The diagnosis of dementia due to Alzheimer's disease: recommendations from the National Institute on Aging-Alzheimer's Association workgroups on diagnostic guidelines for Alzheimer's disease. Alzheimers Dement 2011; 7: 263-9.

3. Wimo A, Jönsson L, Gustavsson A et al. The economic impact of dementia in Europe in 2008-cost estimates from the Eurocode project. Int J Geriatr Psychiatry 2011; 26: 825-32.

4. Ballard C, Gauthier S, Corbett A et al. Alzheimer's disease. Lancet 2011; 377: 1019-31.

5. Fladby T, Mæhlen J. Amyloid- og tau-hypotesene ved degenerativ demens. Tidsskr Nor Lægeforen 1999; 119: 976-9.
6. McKhann G, Drachman D, Folstein M et al. Clinical diagnosis of Alzheimer's disease: report of the NINCDS-ADRDA Work Group under the auspices of Department of Health and Human Services Task Force on Alzheimer's Disease. Neurology 1984; 34: 939-44.

7. Morris JC, Roe CM, Xiong $C$ et al. APOE predicts amyloid-beta but not tau Alzheimer pathology in cognitively normal aging. Ann Neurol 2010; 67: 122-31.

8. Winblad B, Palmer K, Kivipelto M et al. Mild cognitive impairment-beyond controversies, towards a consensus: report of the International Working Group on Mild Cognitive Impairment. J Intern Med 2004; 256: 240-6.

9. Albert MS, DeKosky ST, Dickson D et al. The diagnosis of mild cognitive impairment due to Alzheimer's disease: recommendations from the National Institute on Aging-Alzheimer's Association workgroups on diagnostic guidelines for Alzheimer's disease. Alzheimers Dement 2011; 7: 270-9.

10. Dubois B, Feldman HH, Jacova C et al. Research criteria for the diagnosis of Alzheimer's disease: revising the NINCDS-ADRDA criteria. Lancet Neurol 2007; 6: 734-46.

11. Sperling RA, Aisen PS, Beckett LA et al. Toward defining the preclinical stages of Alzheimer's disease: recommendations from the National Institute on Aging-Alzheimer's Association workgroups on diagnostic guidelines for Alzheimer's disease. Alzheimers Dement 2011; 7: 280-92.

12. Frisoni GB, Hampel H, O'Brien JT et al. Revised criteria for Alzheimer's disease: what are the lessons for clinicians? Lancet Neurol 2011; 10: $598-601$.

13. Buckholtz NS. Perspective: in search of biomarkers. Nature 2011; 475: S8.

14. McKhann GM. Changing concepts of Alzheimer disease. JAMA 2011; 305: 2458-9.

15. Mattsson N, Zetterberg H, Hansson 0 et al. CSF biomarkers and incipient Alzheimer disease in patients with mild cognitive impairment. JAMA 2009; 302: 385-93.

16. Skogseth R, Fladby T, Mulugeta M et al. Biomark $\varnothing-$ rer i spinalvæske ved demens. Tidsskr Nor Legeforen 2011; 131: 2235-8.

17. Walhovd KB, Fjell AM, Amlien I et al. Multimodal imaging in mild cognitive impairment: Metabolism, morphometry and diffusion of the temporal-parietal memory network. Neuroimage 2009; 45: 215-23.

18. Raschetti R, Albanese E, Vanacore $\mathrm{N}$ et al. Cholinesterase inhibitors in mild cognitive impairment: a systematic review of randomised trials. PLoS Med 2007; 4: e338.

Mottatt 8.9. 2011, første revisjon innsendt 28.9. 2011, godkjent 29.9. 2011. Medisinsk redaktør Are Brean. 